\title{
An Observational Study on the Onset of the Summer Monsoon over South China around Hong Kong
}

\author{
By C.H. So and Johnny C.L. Chan \\ Department of Physics and Materials Science, City University of Hong Kong
}

(Manuscript received 1 February 1996, in revised form 22 November 1996)

\begin{abstract}
This paper presents a study of the physical processes responsible for the summer monsoon onset over South China, which is defined using the rainfall data over Hong Kong. Four sets of meteorological parameters are examined: 1) mean-sea-level pressure; 2) surface and upper-level winds; 3) surface and the $850 \mathrm{hPa}$ temperatures; and 4) blackbody temperature $\left(\mathrm{T}_{\mathrm{bb}}\right)$. The first three sets are from the gridded analyses of the European Centre for Medium-Range Weather Forecasts (ECMWF) for the period 1985-1990 while the $\mathrm{T}_{\mathrm{bb}}$ data are from the Geostationary Meteorological Satellite-4 (GMS-4). Daily values of each parameter for the six years are then composited each day for the period ten days before to after the onset day.

The results of the composite study suggest the following sequence of events. Ten days before the onset, a north-south temperature gradient between South China (SC) and northern Australia is first established as the temperature over the latter decreases. This temperature gradient is further enhanced as time goes on when the temperatures over SC and South China Sea (SCS) increase. Development of a surface low over Beibu Wan (around $107^{\circ} \mathrm{E} 18^{\circ} \mathrm{N}$ ) is also observed four days before onset. This surface low deepens throughout the onset period. The enhanced temperature gradient and the deepening of the low apparently lead to an eastward shift of the cross-equatorial flow originally present around $60^{\circ}-80^{\circ} \mathrm{E}$. Together with another branch of this flow within $90^{\circ}$ to $110^{\circ} \mathrm{E}$, the low-level southerly winds over the SCS are therefore enhanced. This results in an increase in low-level convergence in the region of $100^{\circ}-120^{\circ} \mathrm{E}, 15^{\circ}-25^{\circ} \mathrm{N}$ which leads to enhanced rising motion. This is indicated by the enlargement of the $200-\mathrm{hPa}$ anticyclone on $\operatorname{Day}(0)$. The northerlies on the eastern flank of this anticyclone then form a prominent return flow towards the equator. A monsoon trough is thus established along the SC coast and convection activity increases, as indicated by the $\mathrm{T}_{\mathrm{bb}}$ data. This represents the onset of the summer monsoon over South China.
\end{abstract}

\section{Introduction}

A monsoon can be defined as the seasonal reversal of prevailing wind direction. The land-sea contrast created by the enormous land mass of Asia and its adjacent Indian and Pacific Oceans, as well as the special topographic effects (e.g., the Tibetan Plateau), give rise to the most significant monsoon climate over the world. The Asian summer monsoon régime covers two major regions: India and East Asia. The former consists of the Indian Ocean and subcontinent, Arabian Sea, and the Bay of Bengal, while the latter includes China, Japan, Korea, the South China Sea, and the western Pacific Ocean. The common features between the two are the heavy rainfall and prevailing southwesterly wind during the active monsoon period. However, regional differences also exist. The rainfall of the Indian monsoon covers a broad area and is interrupted by intrasea-

(C)1997, Meteorological Society of Japan sonal monsoon breaks (Krishnamurti and Bhalme, 1976). On the other hand, the East Asian summer monsoon has distinctive seasonal rain belt patterns that alternate between quasi-stationary and northward jump stages according to the progression of the Mei-Yu (Baiu) system from spring to summer (Tao and Chen, 1987; Ninomiya and Murakami, 1987).

For the past several decades, the East Asian summer monsoon has been studied by numerous researchers not only due to its significant influence on the social and economic aspects of Asian countries, but also because the circulation of the summer monsoon system (including the onset, maintenance, break and withdrawal) is very extensive and affects the global weather and climate. While early studies on the East Asian summer monsoon focused mainly on events occurring in the months of June, July and August, and in the realm of the Indian monsoon, much more attention has been devoted to the transition seasons (April-May) of the East Asian summer 
monsoon recently. Since the earliest onset appears over South China (Tao and Chen, 1987), the very first step to study the whole monsoon system should be to investigate the East Asian summer monsoon over the South China region.

Climatologically, the onset of the Asian summer monsoon is characterized by the establishment of convection and, of course, the change in the prevailing wind direction to southwesterlies over the area concerned. As discussed in the Science Plan of the South China Sea Monsoon Experiment (Lau and Ding, personal communication), the onset of the East Asian summer monsoon is heralded by the sudden shift of the Intertropical Convergence Zone (ITCZ) from the equatorial region to the South China Sea $\left(10^{\circ} \mathrm{N}\right)$ during the middle of May. Similar sudden transitions were observed by $\mathrm{He}$ et al. (1987) who showed that during the period between mid-April and early July in 1979, the general circulation underwent two distinct stages of abrupt transitions, resulting in the successive onsets of early summer rains over southeast Asia and the Indian summer monsoon. The first transition which is related to the onset occurred in May (coincides with the sudden shift of the ITCZ). The low-level southwesterlies suddenly began over the longitudes east of $80^{\circ} \mathrm{E}$ (from the Bay of Bengal to the South China Sea), resulting in the spread of early summer rains over Assam, the Bay of Bengal coasts of Burma and the Malay Peninsula, Thailand, Indochina and the South China Sea. Also, the centre of the South Asian anticyclone at $200 \mathrm{hPa}$ abruptly moved northward from $10^{\circ}$ to $20^{\circ} \mathrm{N}$.

These previous studies also highlight another important feature about the onset of the summer monsoon: the cross-equatorial flow. Two main crossequatorial flows appear to be related to the Asian summer monsoon. The first is found over the east coast of Africa (the Somali jet) and the other between $100^{\circ}$ to $110^{\circ} \mathrm{E}$ (Tao and Chen, 1987). Traditionally, the East Asian and the Indian monsoons were regarded as one and the same system characterized by the strong low-level southwesterly flow coming from the east coast of Africa extending from the Arabian Sea to southwest China. Wang and Li (1982) suggested that by the time the southwesterly flow over India reaches China, its heat and moisture content are mostly depleted and, therefore, its influence on the monsoon rain over South China will only be marginal at best. It is believed that most of the summer monsoon systems over South China are characterized by the cross-equatorial flow around $100^{\circ} \mathrm{E}$. This branch of the cross-equatorial flow seems to originate from the Australia anticyclone. It then crosses the equator, turning into southwesterlies, and prevails over the South China region. However, Chang and Chen (1995) showed that the effect of the cross-equatorial flow near $105^{\circ} \mathrm{E}$ on the monsoon onset over the South China Sea is not so clear.

The main purpose of this research is therefore to examine the synoptic- and planetary-scale features around the onset time of the summer monsoon over South China (and the northern South China Sea) in an attempt to understand the physical processes responsible for setting up the entire Asian summer monsoon. The onset of the Asian summer monsoon has been defined in a multitude of ways by identifying changes in various parameters such as precipitation, prevailing wind direction and magnitude, or cloud-top temperature/OLR data (e.g., He et al., 1987; Kato and Kodama, 1992; Matsumoto, 1992; Tanaka, 1992; Chen, 1994; Chang and Chen, 1995; Harasawa et al., 1995). In this paper, the onset day is first defined by analyzing the daily rainfall over Hong Kong. This is used to represent the rainfall over South China because it has a very high correlation with that at other stations over South China (Lam, 1993). The synoptic- and planetary-scale surface and upper-level features around the onset day are then studied through a composite study. The term "South China summer monsoon" will be used in this paper to represent the earliest onset of the Asian summer monsoon which occurs around the middle of May and over the South China coastal regions, as pointed out by Tao and Chen (1987).

The data used in defining the onset and the composite studies are described in Section 2 together with the method employed in identifying the onset day. The results of the composite study on the onset characteristics are presented in Section 3. Here, the regional variations of surface features, convection (represented by the blackbody temperature $\mathrm{T}_{\mathrm{bb}}$ ), low-level temperature distribution, and lower and upper tropospheric flow around the onset day are first studied. These regional changes are then related to the circulation on the synoptic and planetary scales. A summary of the results is made in Section 4. Based on these results, a hypothesis on the physical processes that are responsible for the onset of summer monsoon over South China is presented. Future work on how some of the hypothesized processes may be verified will also be discussed.

\section{Data and Methodology}

\subsection{Data sources}

Four sets of data are used in this research:

(1) data from the Monthly Weather Summary published by the Royal Observatory Hong Kong (ROHK);

(2) daily rainfall over Hong Kong from 1884-1939 and 1947-1994 provided by ROHK (104 years);

(3) European Centre for Medium-Range Weather Forecasts (ECMWF) 00 UTC gridded analy- 
ses with a horizontal resolution of $2.5^{\circ}$ latitude square for surface data and $5^{\circ}$ latitude square for upper-level (850, 500 and $200 \mathrm{hPa}$ ) data from 1985 to 1990 (the Tropical-Ocean-GlobalAtmosphere (TOGA) data set);

(4) daily averaged blackbody temperature $\left(\mathrm{T}_{\mathrm{bb}}\right)$ data from the Geostationary Meteorological Satellite (GMS) from 1985-1990.

The first set of data provides surface winds over Hong Kong and daily weather charts to help define the onset. The second set of data allows the calculation of a long-term average rainfall over Hong Kong which is then used as one of the onset criteria (detail of the definition of the onset will be given on the next section). The composite study (see Section 3.2) makes use of the ECMWF data which consist of the mean-sea-level pressure (MSLP), zonal and meridional winds at $10 \mathrm{~m}$, temperature at $2 \mathrm{~m}$, as well as these parameters and geopotential heights at 850,500 and $200 \mathrm{hPa}$. The last set of data is used to infer the presence of strong convection.

\subsection{Methodology}

To define the summer monsoon onset over South China, the 5-day weighted running total (to eliminate the daily fluctuation of the rainfall data) rainfall of ROHK from April to June for the entire 104 years is first calculated. Hong Kong is chosen as the station for defining the onset because the earliest mean onset day isochrone (10 May) is over the South China (SC) coastal region, including Hong Kong (Tao and Chen, 1987). A very high correlation also exists among the rainfall measurements of stations over SC (Lam, 1993). This five-day total rainfall is found to be $46 \mathrm{~mm}$, which is then used as a threshold for defining the onset. Specifically, the following four criteria are used to define the onset day:

(1) The date selected should be between 10 April and 10 July. This range is selected (a) based on the mean onset date of 10 May for the summer monsoon over SC (Tao and Chen, 1987) and (b) to avoid identifying rainfall episodes due to the passage of a cold front, which can occur in late March and early April.

(2) The 5-day weighted running total ROHK rainfall should be $\geq 46 \mathrm{~mm}$.

(3) The meridional wind over Hong Kong is positive on the onset day.

(4) There should be no Tropical Cyclone (TC) between $110^{\circ}-125^{\circ} \mathrm{E}$ and $10^{\circ}-25^{\circ} \mathrm{N}$ in order to eliminate the case which the rain was brought about by the TC.
Table 1. The onset day of the six summers from 1985-1990.

\begin{tabular}{cc}
\hline Year & Onset \\
\hline 1985 & 10 April \\
1986 & 20 April \\
1987 & 16 May \\
1988 & 22 June \\
1989 & 30 April \\
1990 & 31 May \\
\hline
\end{tabular}

Figures $1 \mathrm{a}-\mathrm{f}$ show the rainfall and meridional wind over Hong Kong from 1985-1990. Take 1989 as an example. The onset day is identified as 30 April since it is the first day after 10 April with the five-day running total rainfall exceeding $46 \mathrm{~mm}$ and a southerly wind. It can also be seen that there is little rainfall before the onset. A break of the monsoon can also be seen after the onset and is followed by another heavy rainfall period around 20 May.

The onset days of the six summers are shown in Table 1. The mean onset day is 12 May, which is very close to that from Tao and Chen (1987) despite the relatively small sample size. The range of the onset days is quite large, the earliest one appearing on 10 April in 1985 and the latest one 22 June in 1988. The early onset in 1985 is obvious from Fig. 1a since the next episode of heavy rain did not occur until late June. On the other hand, in 1988, a relatively dry period prevailed from April to midJune. It is therefore a year of "late onset". Since the most important effect of the summer monsoon is heavy rainfall, assigning 1985 and 1988 as years of "early onset" and "late onset" respectively seems to be reasonable.

After the onset for each year has been defined, the daily (00 UTC) dynamic and thermodynamic parameters from the ECMWF data set for the six years are composited relative to the onset date in the area of $40^{\circ}-180^{\circ} \mathrm{E}$ and $40^{\circ} \mathrm{S}-40^{\circ} \mathrm{N}$. This region is selected to include the subtropical high over the western Pacific, the east coast of Africa (the Somali jet), the anticyclone over Australia (possible origin of cross-equatorial flows) and northern China. A time-span of 21 days (10 days before and after the onset respectively) is used in the composite study. These 21 days are denoted as Day $(-10)$, Day $(-9)$, ....., $\operatorname{Day}(-1), \operatorname{Day}(0), \operatorname{Day}(1), \ldots . ., \operatorname{Day}(9)$ and $\operatorname{Day}(10)$, with $\operatorname{Day}(0)$ being the onset day.

\section{Onset characteristics}

The results presented in this section are composites of the six years from 1985-1990 using the ECMWF and GMS $\mathrm{T}_{\mathrm{bb}}$ data sets. The averaging is done by aligning the six onset days and the mean of each parameter for each day is then taken. 

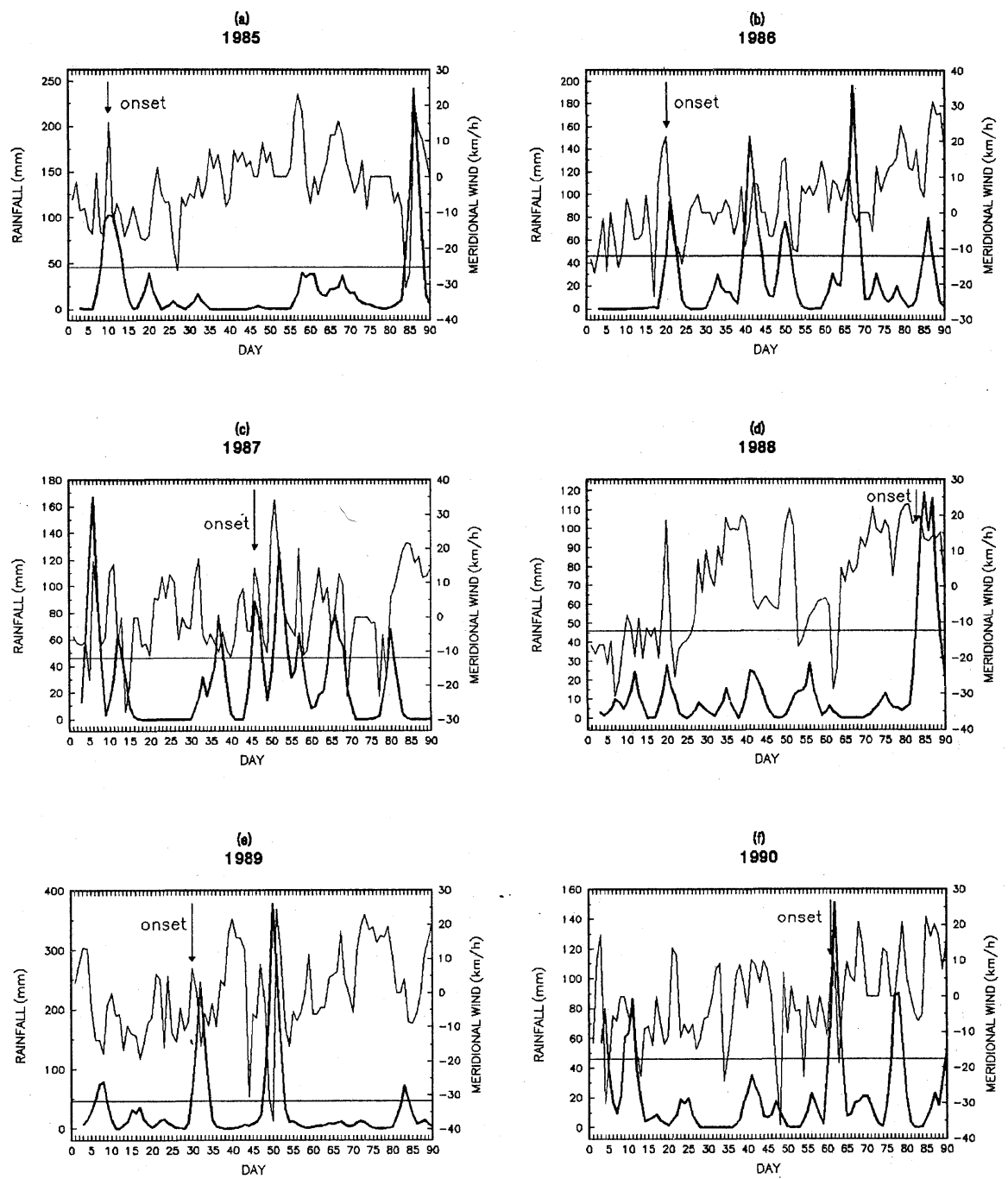

Fig. 1. Five-day weighted running total rainfall (solid) and daily meridional wind (dot dashed) over Hong Kong during April to June from 1985 to 1990 (a to f). The day number starts on 1 April (i.e., day number 1$)$. The dotted line indicates the long-term five-day running total rainfall (46 mm).

\subsection{Regional variations}

3.1.1 Surface features and $T_{\mathrm{bb}}$

The variations of MSLP, surface meridional wind, surface temperature and $\mathrm{T}_{\mathrm{bb}}$ from $\operatorname{Day}(-10)$ to $\operatorname{Day}(10)$ over the SC coastal region $\left(20-25^{\circ} \mathrm{N}, 112.5-\right.$ $117.5^{\circ} \mathrm{E}$ ) are shown in Figs. 2a-d. The pressure first rises gradually from $\operatorname{Day}(-10)$ to $\operatorname{Day}(-5)$, and then a sharp drop of about $5 \mathrm{hPa}$ occurs from Day $(-5)$ to $\operatorname{Day}(1)$ (Fig. 2a). From $\operatorname{Day}(1)$ to $\operatorname{Day}(3)$, the pressure shows a slight rise of about $1 \mathrm{hPa}$ and then maintains a relatively low value of around $1010 \mathrm{hPa}$ for the rest of the days.

The surface meridional wind switches from northerly to southerly on $\operatorname{Day}(-4)$, which lags behind the beginning of the pressure drop by one day (Fig. 2b). This suggests the lowering of the MSLP as a possible cause for the southerly wind over South China during the onset. Another interesting result is that the day when maximum southerlies occur is on $\operatorname{Day}(0)$ with a value of about $2 \mathrm{~m} \mathrm{~s}^{-1}$. Recall that the third criterion for the onset is the requirement of positive meridional wind only. However, this sixyear composite shows that the meridional wind is not only southerly but also reaches its maximum on the onset day.

The surface temperature shows an initial decrease from $\operatorname{Day}(-10)$ to $\operatorname{Day}(-8)$, followed by a continuous increase to Day $(0)$ with a difference of about $2^{\circ} \mathrm{C}$ compared to Day (-8) (Fig. 2c). The fact that such an increase precedes the drop in the MSLP and the weakening of the northerlies (by three and two days respectively) suggests that heating over SC may be a possible cause of the onset.

The $\mathrm{T}_{\mathrm{bb}}$ data indicate that the convective activity over the SC region abruptly increases from Day $(-1)$ to $\operatorname{Day}(1)$ (Fig. 2d). This result is consistent with the sudden shift of the Intertropical Convergence Zone (ITCZ) from the equatorial region to the South 
(a)

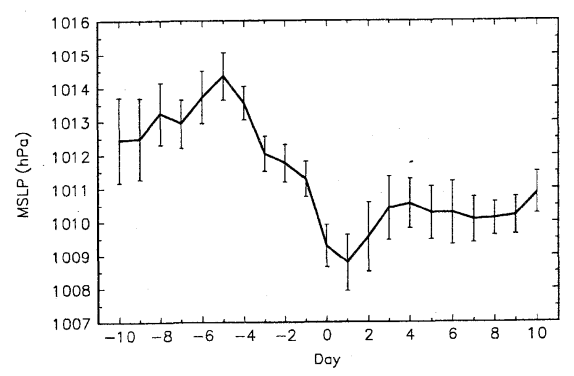

(c)

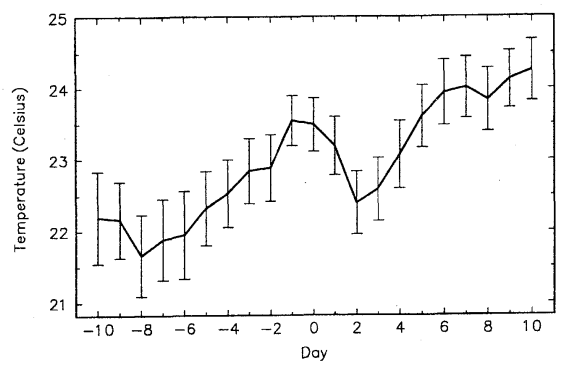

(b)

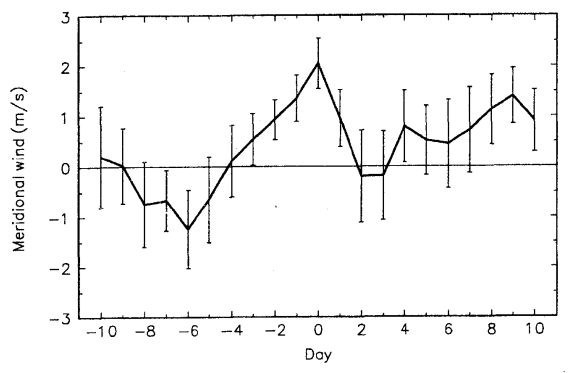

(d)

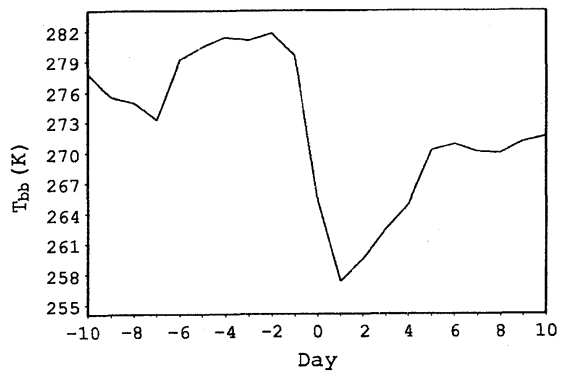

Fig. 2. Regional variations (averaged between $20^{\circ}-25^{\circ} \mathrm{N}, 112.5^{\circ}-117.5^{\circ} \mathrm{E}$ ) of (a) MSLP, (b) meridional wind, (c) surface temperature and (d) $\mathrm{T}_{\mathrm{bb}}$ relative to Day(0). The error bars in (a)-(c) represent the standard errors.

China Sea during onset in the middle of May found by Yang et al. (1994) from studying 17 years of outgoing longwave radiation (OLR) data. The convection apparently lasts for about four days. This increase in convection is also consistent with the lowering of the surface temperature during this period (Fig. 2c) due to the heavy precipitation.

\subsubsection{Low-level temperature distribution}

Much attention has been focused on the maintenance of the East Asian summer monsoon by the heat source over the South China Sea (SCS) and the sink over northern Australia (e.g., Chen and Li, 1981) which sets up a temperature gradient between the two hemispheres. In order to study the effect of this pair of heat source and sink on the onset, the time variations of the $850-\mathrm{hPa}$ temperature over the northern part of the SCS $\left(110^{\circ}-120^{\circ} \mathrm{E}, 15^{\circ}-20^{\circ} \mathrm{N}\right)$ and northern part of Australia $\left(110^{\circ}-120^{\circ} \mathrm{E}, 15^{\circ}-\right.$ $20^{\circ} \mathrm{S}$ ) are examined. They show a temperature gradient being set up in the meridional direction in the longitudinal range of $110^{\circ}-120^{\circ} \mathrm{E}$, and between $20^{\circ} \mathrm{N}$ and $20^{\circ} \mathrm{S}$ (Fig. 3). It should be pointed out that the temperature in the equatorial region within this longitude band is found to be around $18.5^{\circ} \mathrm{C}$ throughout the whole period (not shown). Therefore, it will not act as a 'thermal barrier' for the setting up of the temperature gradient between the two hemispheres.

The temperature over the SCS begins to rise on $\operatorname{Day}(-6)$ from the value of about $18.5^{\circ} \mathrm{C}$, which is one day before the MSLP begins to drops over SC and on the same day when the northerly wind begins

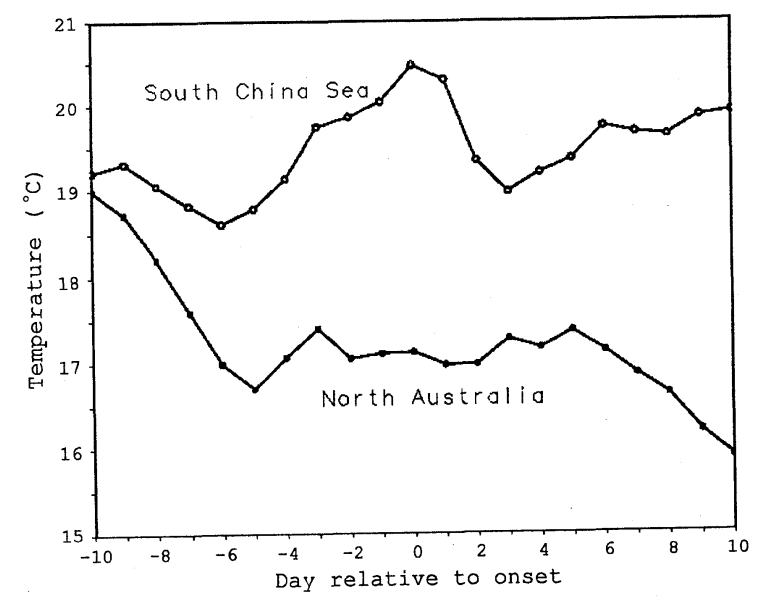

Fig. 3. The $850-\mathrm{hPa}$ temperatures over northern South China Sea $\left(110^{\circ}-120^{\circ} \mathrm{E}, 15^{\circ}-20^{\circ} \mathrm{N}\right)$ and northern Australia $\left(110^{\circ}-120^{\circ} \mathrm{E}, 15^{\circ}-20^{\circ} \mathrm{S}\right)$ relative to $\operatorname{Day}(0)$.

to weaken. It then reaches a maximum of $20.5^{\circ} \mathrm{C}$ on Day(0) which also corresponds to the maximum southerly wind over Hong Kong. On the other hand, the temperature over northern Australia begins to drop on Day (-10) until Day (-5), and then maintains a value of about $17^{\circ} \mathrm{C}$ until Day(5). This gives the maximum $850-\mathrm{hPa}$ temperature difference between the SCS and northern Australia of about $3.5^{\circ} \mathrm{C}$ on $\operatorname{Day}(0)$. 


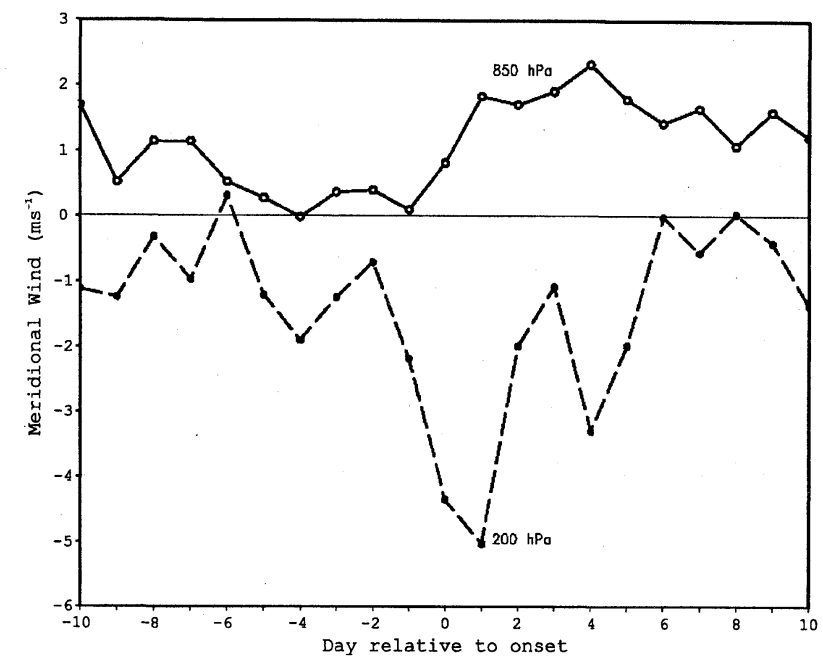

Fig. 4. The average meridional wind at 850 (solid) and 200 (dashed) $\mathrm{hPa}$ in the region $110^{\circ}-120^{\circ} \mathrm{E}, 10^{\circ}-20^{\circ} \mathrm{N}$.

While previous research (Tao and Chen, 1987) suggested that this pair of heat source and sink maintains the circulation of the Asian summer monsoon, this result suggests that such a pair may also play a role in initiating the onset of the summer monsoon over South China. Furthermore, it can also explain the behaviour of the surface meridional wind after Day(0) (see Fig. 2b). Through Day(0) to Day(3), the north-south temperature gradient is reduced due to the temperature decrease over the SCS together with little variation in north Australia. This is consistent with the weakening of the southerly wind over SC. On Day(3), the southerly wind begins to strengthen again which corresponds to the temperature rises over SCS on the same day.

\subsubsection{Lower and upper tropospheric flow}

Lau and Li (1984) showed that during the Asian summer monsoon period, the local Hadley circulation between $75^{\circ}-110^{\circ} \mathrm{E}$ is manifested in a poleward surface flow toward the elevated Tibetan heat source, with equatorward return flow aloft. Similar results are found during the onset in the meridional wind at 850 and $200 \mathrm{hPa}$ in the region $110^{\circ}-120^{\circ} \mathrm{E}$ and $10^{\circ}-20^{\circ} \mathrm{N}$ (Fig. 4). This region is chosen because the main heat source during the onset period has been identified to be the SCS as discussed above. It is found that this region is dominated by upperlevel northerlies and lower-level southerlies, with the significant increase beginning to occur on $\operatorname{Day}(-2)$ for the upper-level northerlies and Day $(-1)$ for the lower-level southerlies.

\subsubsection{Summary}

Summarizing the regional behaviour during the onset period, a sequence of events can be identified prior to the onset: Starting from $\operatorname{Day}(-10)$, a drop of the surface temperature over northern Australia is observed. It continues to decrease until on Day $(-8)$, while the surface temperature over South China (SC) begins to rise. Therefore, a north-south temperature gradient begins to be set up. The 850$\mathrm{hPa}$ temperature over the South China Sea (SCS) begins to rise on $\operatorname{Day}(-6)$ together with the weakening of the meridional wind over SC. The MSLP over $\mathrm{SC}$ begins to decrease on $\mathrm{Day}(-5)$, and the $850-\mathrm{hPa}$ temperature over northern Australia also reaches its minimum $\left(16.5^{\circ} \mathrm{C}\right)$ at the same time. The meridional flow over SC switches from weak northerly to southerly on Day $(-4)$. On Day $(-2)$, the $200-\mathrm{hPa}$ northerly wind in the region $110^{\circ}-120^{\circ} \mathrm{E}, 10^{\circ}-20^{\circ} \mathrm{N}$ strengthens, which forms a return flow with the lowlevel southerly when the $850-\mathrm{hPa}$ southerly wind increases on Day $(-1)$. At the same time, a sudden decrease of $T_{b b}$ value is observed. On $\operatorname{Day}(0)$, maximum meridional wind $\left(\sim 2 \mathrm{~m} \mathrm{~s}^{-1}\right)$, surface and 850-hPa temperature over SC $\left(23.5^{\circ} \mathrm{C}\right.$ and $20.5^{\circ} \mathrm{C}$ respectively) are found. On the other hand, the minimum values of MSLP (1009 hPa) and $\mathrm{T}_{\mathrm{bb}}(258 \mathrm{~K})$ are reached on Day(1). In order to determine the causes of these regional changes, the synoptic-scale and time-longitude changes are examined in the next two sub-sections.

\subsection{Synoptic-scale features}

\subsubsection{MSLP}

On Day $(-4)$, the composite MSLP shows that the subtropical ridge lies along the coast of southeast China (Fig. 5a). Therefore, before onset, the $\mathrm{SC}$ and the SCS regions are mainly under the influence of the subtropical high. This result is generally consistent with the relatively high value of $\mathrm{T}_{\mathrm{bb}}$ on Day $(-4)$. Also notice a small low pressure system $(1010 \mathrm{hPa})$ centred at about $107^{\circ} \mathrm{E}, 18^{\circ} \mathrm{N}$. Two days later, this surface low deepens to $1008 \mathrm{hPa}$ and expands in horizontal extent (Fig. 5b). As a result, the MSLP over southeast China decreased, as indicated by the northeastward displacement of the 1011-hPa isobar. This situation continues to Day(0) when the low reaches its lowest value of $1006 \mathrm{hPa}$ (Fig. 5c). The 1011-hPa isobar now retreats to the north of Shanghai. A trough is thus found to lie along the coast of south and southeast China. The subtropical high is now east of Taiwan.

\subsubsection{Cross-equatorial flow}

Previous studies (e.g., Lau and Li, 1984; Tao and Chen, 1987) have shown that the large-scale mean circulation of the East Asian summer monsoon is characterized by strong cross-equatorial flows from the southern to the northern hemisphere in the lower troposphere, near the longitudes of the east coast of Africa and the maritime continent of Borneo and Indonesia. A strong westerly flow over South India and southwesterly flow over China are also observed. Similar results are found during the onset period in 
(a)

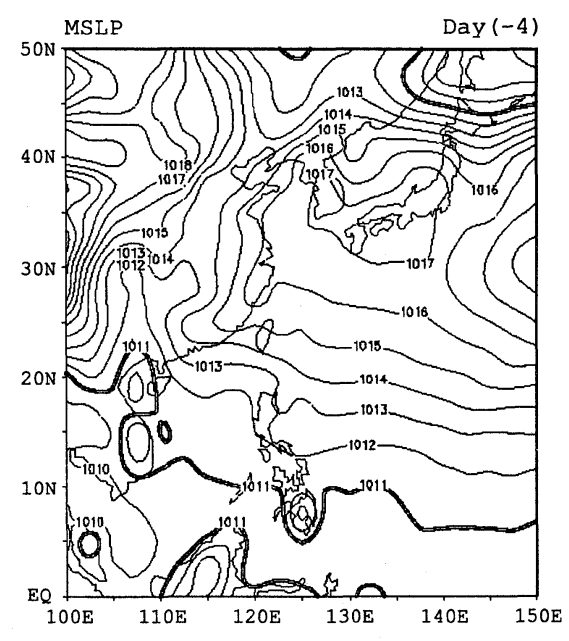

(c)

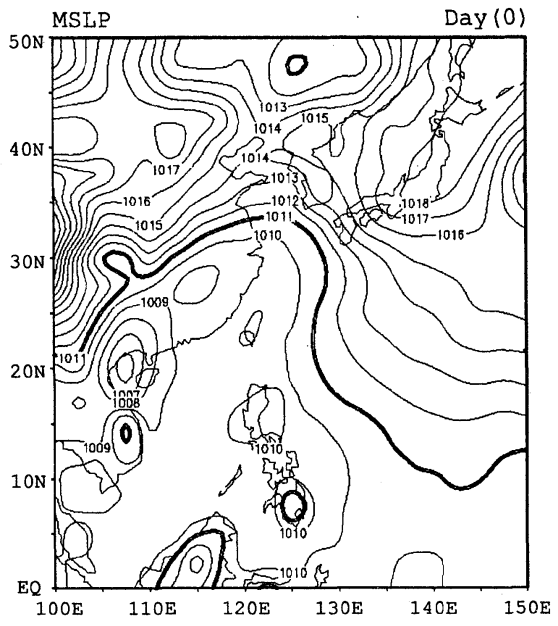

(b)

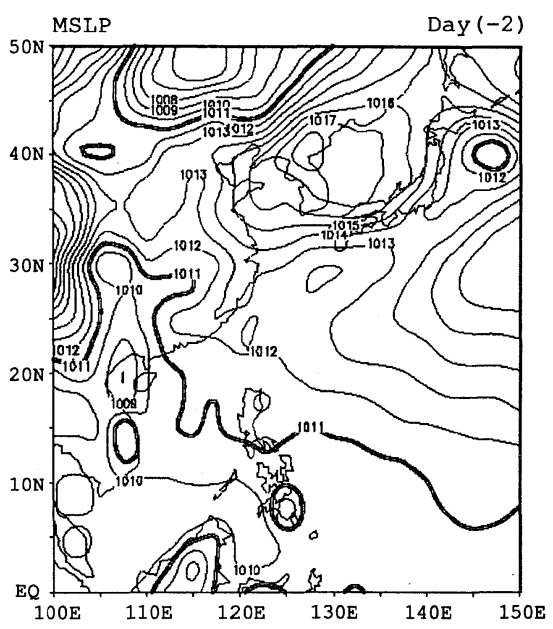


(a)

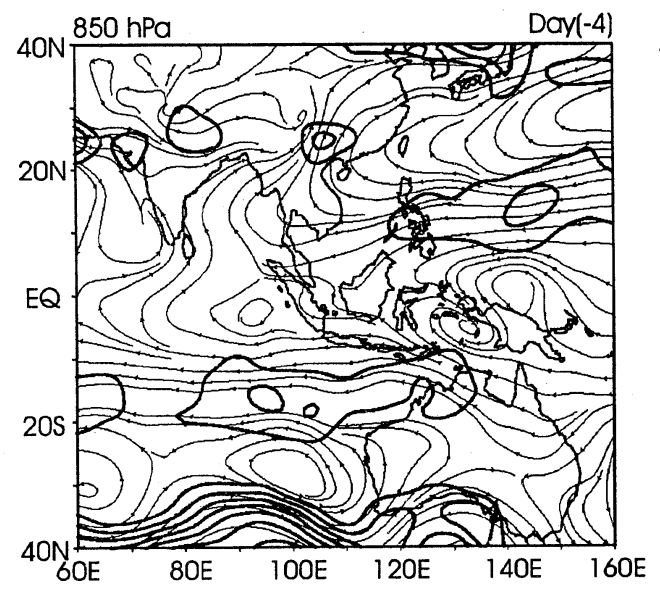

(b)

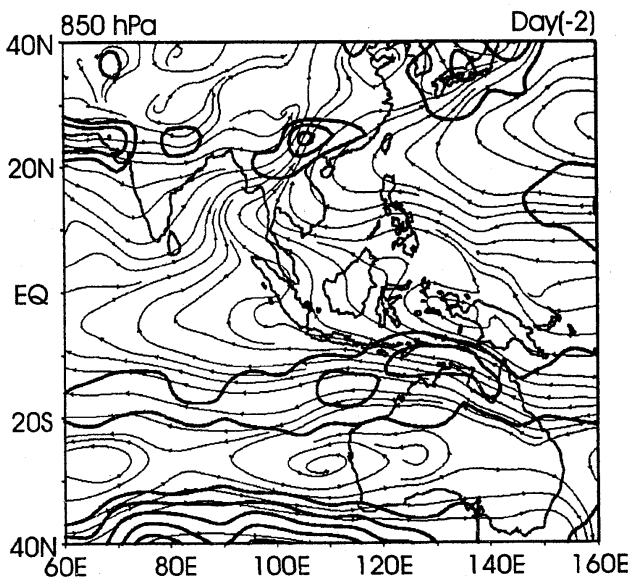

(c)

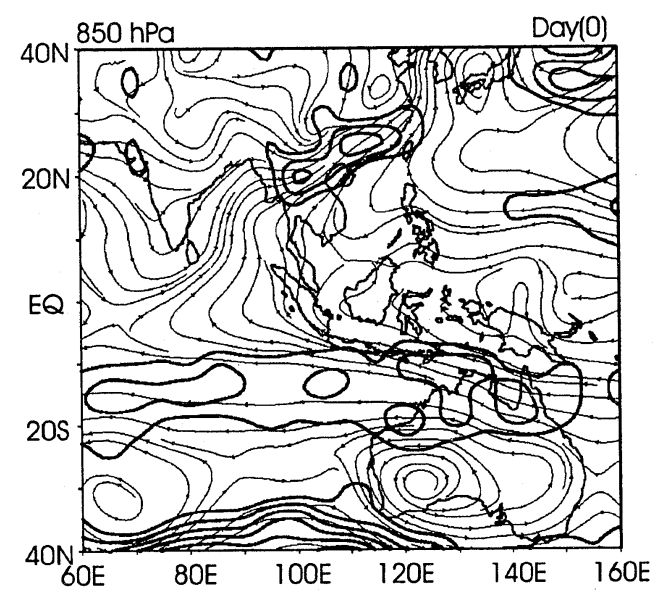

Fig. 6. Composites of the 850-hPa flow on (a) Day(-4), (b) Day(-2) and, (c) Day(0). Each contour level represents $2 \mathrm{~m} \mathrm{~s}^{-1}$ and only those greater than $6 \mathrm{~m} \mathrm{~s}^{-1}$ are plotted.

crease in the divergence in the upper-levels (not shown). On Day (-2), a pair of 200-hPa anticyclones are found in the northern and southern hemispheres along $115^{\circ} \mathrm{E}$ (Fig. 7a). Tao and Chen (1987) showed the existence of a huge anticyclone on the $200 \mathrm{hPa}$ level in July over southern Asia. The one found here during the onset period may be related to the one found during the active monsoon period. It appears that an exchange of energy occurs between the two hemispheres, with the size of the northern hemisphere anticyclone enlarging on Day $(0)$ and the one in the southern hemisphere decreased two days later (Fig. 7b). Energy is thus transported from the southern to the northern hemisphere in the lower atmosphere. This energy exchange may be brought about by the low-level cross-equatorial flow which converges below the upper-level anticyclone. The enlargement of the anticyclone on $\operatorname{Day}(0)$ leads to the enhancement of northerly flow to its east. This is consistent with the strengthening of the $200-\mathrm{hPa}$ northerly wind flow described in the previous section
(Fig. 4). This enhanced upper-level northerly flow forms a return flow with the lower-level southerlies which bring more moisture-laden air to the South China regions, thus, favoring convective activities during onset.

\subsection{Time-longitude cross-sections}

To investigate further the time changes of the circulation over the South China regions, timelongitude cross-section of MSLP $\left(17.5^{\circ}-22.5^{\circ} \mathrm{N}\right.$, $22.5^{\circ}-27.5^{\circ} \mathrm{N}$ and, $\left.27.5^{\circ}-32.5^{\circ} \mathrm{N}\right), 200-\mathrm{hPa}$ zonal wind $\left(17.5^{\circ}-22.5^{\circ} \mathrm{N}\right), 850-\mathrm{hPa}$ temperature $\left(20^{\circ}-\right.$ $\left.25^{\circ} \mathrm{N}\right)$ and, the $\mathrm{T}_{\mathrm{bb}}\left(20^{\circ}-25^{\circ} \mathrm{N}\right)$ are examined. The development of a surface low over Beibu Wan (around $107^{\circ} \mathrm{E} 18^{\circ} \mathrm{N}$ ) as described in the previous section is clearly seen in Fig. 8a. This diagram indicates an in-situ deepening of the low from about $1010 \mathrm{hPa}$ on Day(-4) to $1007 \mathrm{hPa}$ on Day(0), and a subsequent eastward enlargement to $120^{\circ} \mathrm{E}$ on Day(0). The northern part of this low is seen to propagate eastward from $\operatorname{Day}(-3)$ to $\operatorname{Day}(0)$ (Fig. 
(a)

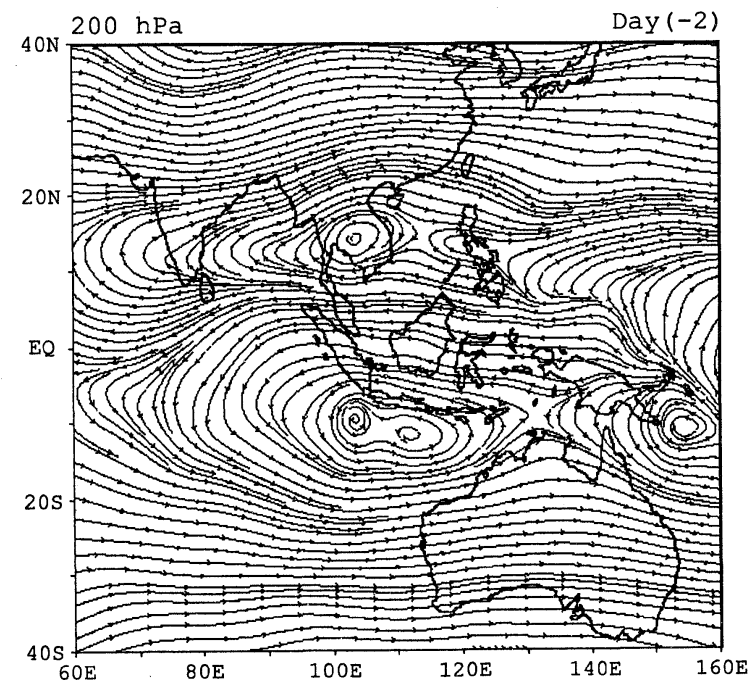

(b)

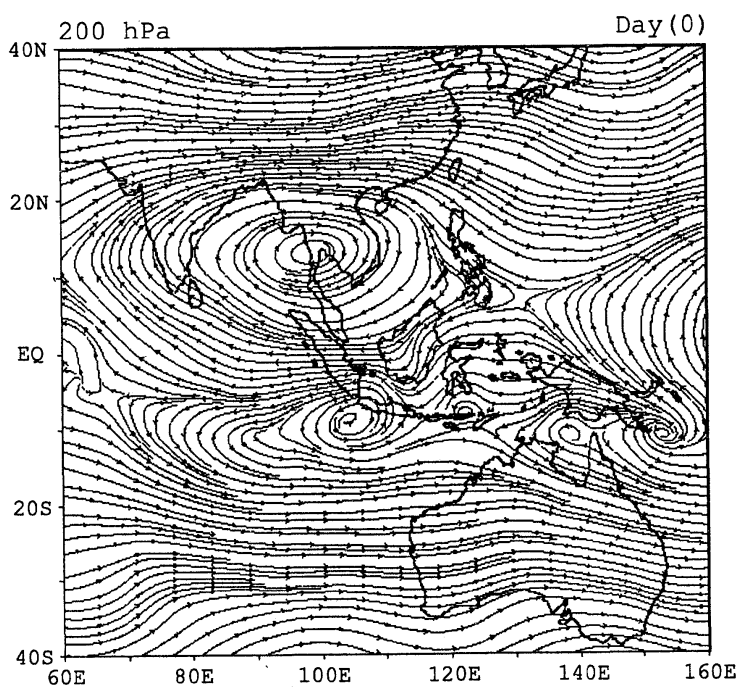

Fig. 7. The composites of the 200-hPa streamlines on (a) $\operatorname{Day}(-2)$ and, (b) $\operatorname{Day}(0)$.

8b). A similar propagation of the low pressure can also be seen further to the north at around $30^{\circ} \mathrm{N}$ (Fig. 8c).

The abrupt increase in heating between $105^{\circ}$ and $125^{\circ} \mathrm{E}$ on Day $(-4)$ (as indicated by the $18^{\circ} \mathrm{C}$ isotherm can be seen from the $850-\mathrm{hPa}$ temperature (Fig. 9a). The rising trend in temperature before onset and the sudden drop after the onset followed by another rise is generally consistent with the one shown in Fig. 3. A similar increase in temperature over the SCS $\left(15^{\circ}\right.$ to $\left.20^{\circ} \mathrm{N}\right)$ is also found (Fig. $9 \mathrm{~b}$ ). These temperature increases may be due to horizontal advection from the west or local diabatic heating. Since SC is generally free of convection before Day (-1) (see Fig. 2c), heating due to radiation forcing may have a significant effect on the surface warming. At the same time, heat energy may be (a)

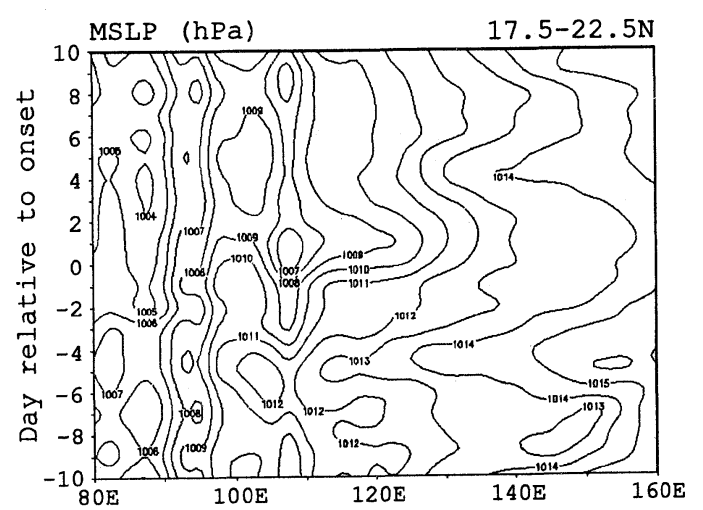

(b)

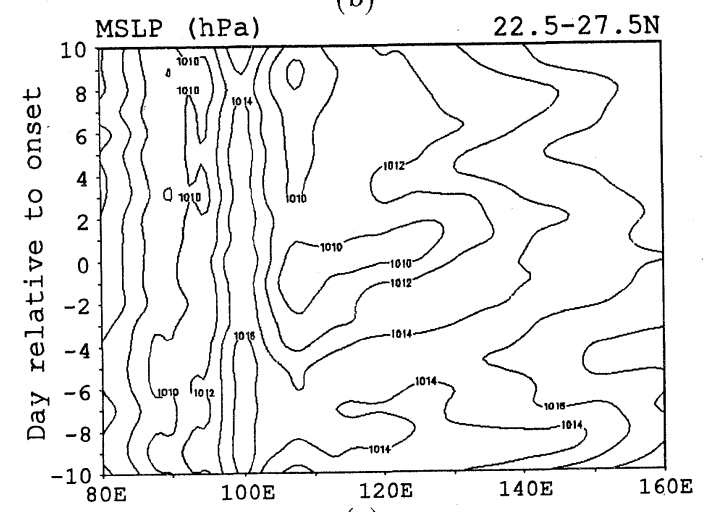

(c)

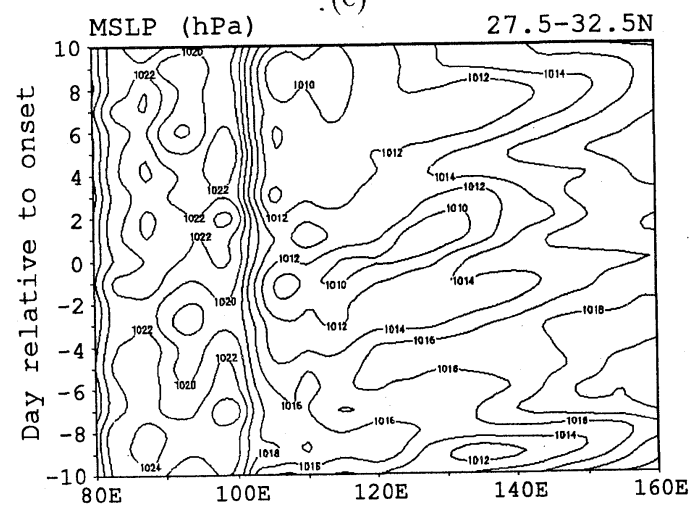

Fig. 8. The Hovmoller diagrams of (a) MSLP averaged between $17.5^{\circ}$ and $22.5^{\circ} \mathrm{N}$, (b) MSLP averaged between $22.5^{\circ}$ and $27.5^{\circ} \mathrm{N}$, (c) MSLP averaged between $27.5^{\circ}$ and $32.5^{\circ} \mathrm{N}$.

transported from the west by the low-level southwesterlies mentioned in the previous section. The idea of horizontal warm advection over the South China Plain was supported by the work of Yanai et al. (1992).

The three branches of southwesterly flows (see Fig. 6) are believed to be the major routes of heat and moisture transport to the SC region: 1) the southwesterlies from the Bay of Bengal, passing through the Indian subcontinent and originates from the cross-equatorial flow in the Arabian Sea; 2) the 
(a)

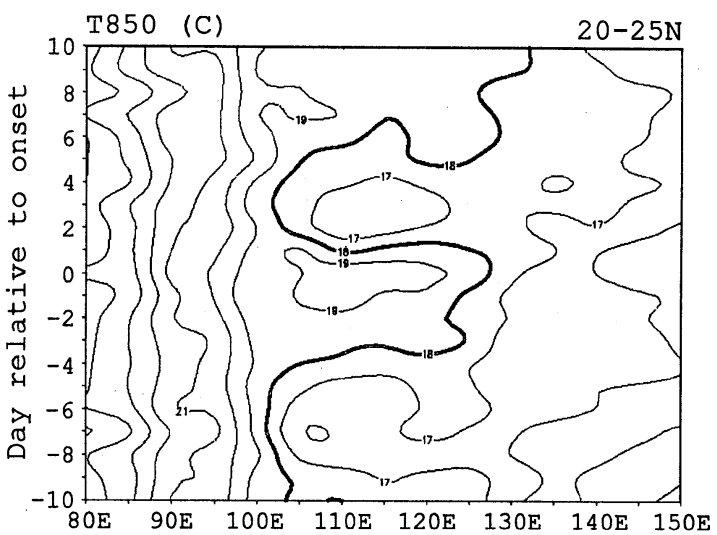

(b)

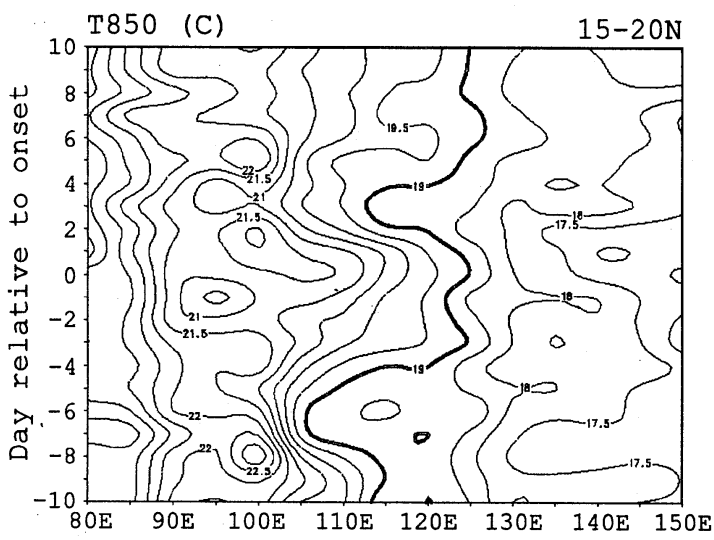

Fig. 9. The Hovmoller diagrams of (a) 850$\mathrm{hPa}$ temperature averaged between $20^{\circ}$ to $25^{\circ} \mathrm{N}$, (b) $15^{\circ}$ to $20^{\circ} \mathrm{N}$.

southwesterlies from another cross-equatorial flow around $100^{\circ} \mathrm{E}$ and; 3) the southwesterlies from the western flank of the subtropical high. All three branches transport moisture over the warm South China Sea (and also from the Bay of Bengal for the first one) during the pre-summer rainy season. These southwesterlies also extract considerable latent heat from the ocean (Tao and Chen, 1987).

The abrupt increase in convection on $\operatorname{Day}(-1)$ can be seen from Fig. 10. Before Day $(-1)$, little intense convection (high value of $\mathrm{T}_{\mathrm{bb}}$ ) exists over the $\mathrm{SC}$ regions $\left(110^{\circ}-120^{\circ} \mathrm{E}, 20^{\circ}-25^{\circ} \mathrm{N}\right)$. The strongest convection appears on $\operatorname{Day}(0)$ and $\operatorname{Day}(1)$, with a minimum $\mathrm{T}_{\mathrm{bb}}$ value of $261 \mathrm{~K}$. This is consistent with the local abrupt change in $T_{b b}$ value showed in Section 3.1 (Fig. 2d) and the increase in low-level convergence mentioned in the previous section.

He et al. (1987) showed that, from spring to summer 1979, the general circulation over Asia underwent two distinct stages of abrupt transition, resulting in the successive onsets of the early summer rains over Southeast Asia, the South China Sea and the Indian subcontinent. The first transition occurred in May and this onset-related transition is related

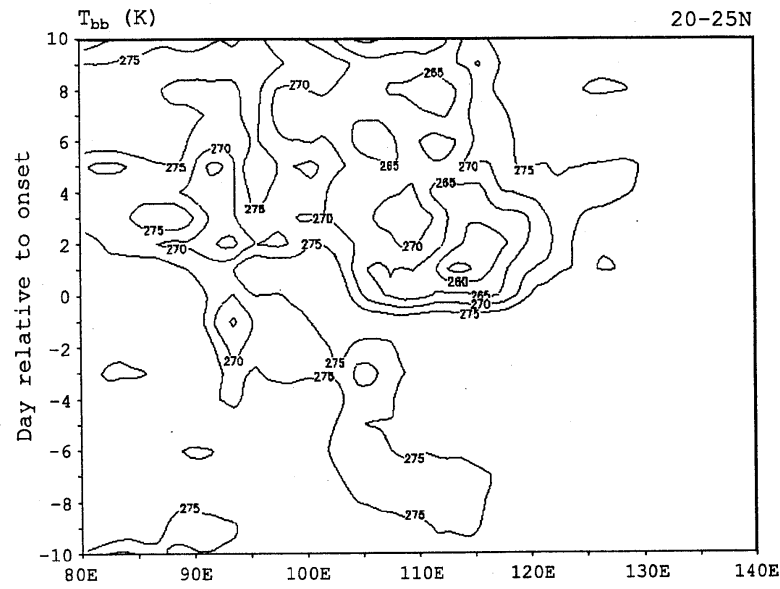

Fig. 10. The Hovmoller diagram of GMS $\mathrm{T}_{\mathrm{bb}}$ averaged between $20^{\circ}$ and $25^{\circ} \mathrm{N}$ (only values below $275 \mathrm{~K}$ are plotted, unit for the $\mathrm{T}_{\mathrm{bb}}$ is $\mathrm{K}$ ).

well to a similar stage of upper tropospheric warming over the Asian land mass. The idea is used here to see the warming over the South China land mass during onset. While the 5-day mean deviation of the $200-500 \mathrm{hPa}$ layer mean temperature at $32.5^{\circ} \mathrm{N}$ was used by $\mathrm{He}$ et al. (1987) to study the effect of Tibetan Plateau, the daily deviation of the $850-\mathrm{hPa}$ temperature from the mean of the 21 days at $25^{\circ} \mathrm{N}$ is examined here (Fig. 11a). Similar results are found during the South China summer monsoon onset in that a rapid warming occurs first over the longitudes between $100^{\circ}$ and $125^{\circ} \mathrm{E}$ (the South China Plain) on about Day $(-5)$ to Day $(-4)$. The rapid cooling after the onset to Day(4) is consistent with the previous results and may be due to the heavy rainfall. The warming over these regions is the primary cause of the reversal of the meridional temperature difference between $5^{\circ}$ and $25^{\circ} \mathrm{N}$ (Fig. 11b).

\subsection{Summary}

The results presented in this section illustrate the relationships between the regional changes prior to the onset and the synoptic- and even planetary-scale changes. Apparently, the latter are responsible for bringing about the occurrence of the former, which then leads to the onset of the summer monsoon over South China. Such cause-and-effect relationships together with some hypothesized mechanisms for these causalities will be discussed in the next section.

\section{Conclusions}

\subsection{Summary and discussion}

In this study, the physical processes that may lead to the onset of summer monsoon over South China are examined. The onset is defined by using the ROHK rainfall data, which can be used to represent the rainfall over the SC regions (Lam 1993). The 
(a)

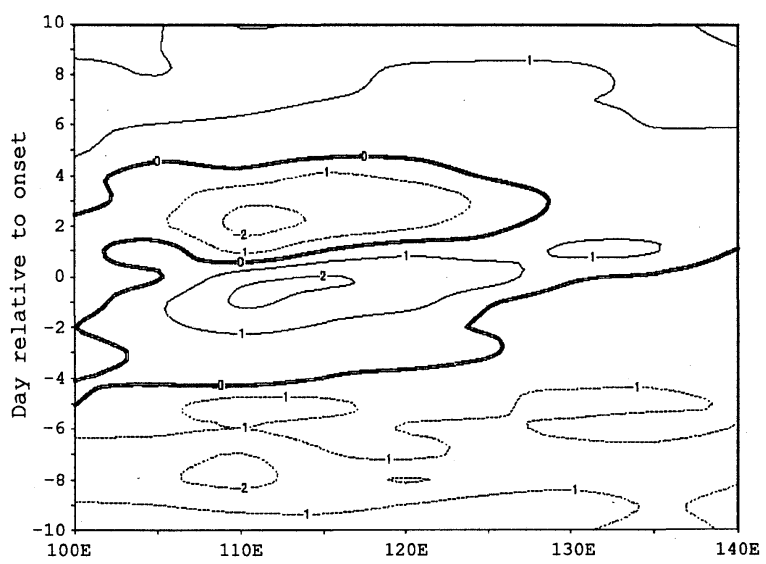

(b)

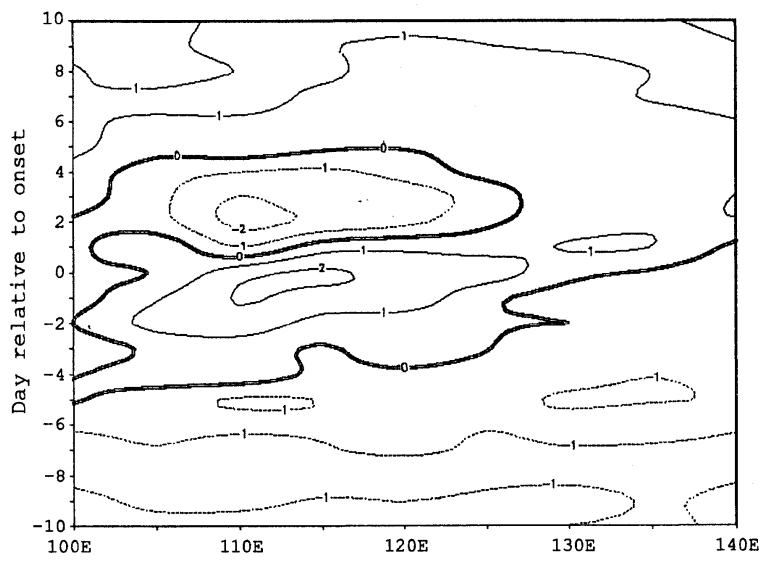

Fig. 11. Longitude-time sections for (a) the deviation of the $850-\mathrm{hPa}$ mean temperature $\left({ }^{\circ} \mathrm{C}\right)$ at $25^{\circ} \mathrm{N}$ and, (b) the meridional dffference of the $850-\mathrm{hPa}$ mean temperature $\left({ }^{\circ} \mathrm{C}\right)$ between $5^{\circ}$ and $25^{\circ} \mathrm{N}$. The thicker line indicates the $0^{\circ} \mathrm{C}$ isotherm.

ECMWF analyses and GMS $\mathrm{T}_{\mathrm{bb}}$ data for six summers from 1985 to 1990 are then composited relative to the onset day. In addition, some of the major characteristic atmospheric features associated with the onset are examined (such as the surface low development and the occurrence of the cross-equatorial flows) which show that the results found in the composites are not artifacts of the averaging process.

The time sequence of the major changes before onset are shown in Table 2. Significant changes occur as early as ten days before the onset. A north-south temperature gradient is first set up as indicated by the temperature decrease over north Australia. This is also the time when the cross-equatorial flow begins a trend of steady increase (not shown). Another phenomenon signaling the onset is the rise in surface temperature over SC on Day $(-8)$. This increase continues until the onset occurs. On Day $(-6)$, the temperature over SCS starts to increase, which lags behind the one over SC. The temperature gradient between the two hemispheres is therefore enhanced. At the same time, the northerly wind over SC begins to weaken. This continues until Day $(-4)$ when the winds become southerly. This may be due to the cross-equatorial flow observed between $60^{\circ}$ and $80^{\circ} \mathrm{E}$ on the same day. It may also be caused by the development of a surface low (or a cyclogenesis) over Beibu Wan.

Another phenomenon on Day $(-4)$ is the increase of the low-level convergence as indicated by the 850$\mathrm{hPa}$ wind. Two days later, another cross-equatorial flow is observed between $90^{\circ}$ and $110^{\circ} \mathrm{E}$, which further enhances the southerly wind over SC and brings moist air from the ocean. Chang and Chen (1995) suggested that the significance of the crossequatorial flow near $105^{\circ} \mathrm{E}$ is not clear in enhancing the southerly wind over SC. In this study, however, the occurrence of this cross-equatorial flow plays a role in increasing the southwesterly component of the wind field over SC two days before the onset by providing an extra branch of southwesterly wind other than the one which comes from the cross-equatorial flow between $60^{\circ} \mathrm{E}$ and $80^{\circ} \mathrm{E}$. As the low-level convergence continues to increase and extends to the $\mathrm{SC}$ regions (not shown), the blackbody temperature $\left(\mathrm{T}_{\mathrm{bb}}\right)$ shows a sudden drop on $\operatorname{Day}(-1)$ which indicates a sudden increase in convective activity. Finally, the low-level convergence (not shown) causes the increase of upper-level divergence as indicated by the $200-\mathrm{hPa}$ anticyclone.

Based on these results, a flow chart can be made to describe the events that lead to the onset of East Asian summer monsoon onset (Fig. 12).

Before onset, there is development of a surface low (or cyclogenesis) in Beibu Wan. This surface low deepens as time goes to $\operatorname{Day}(0)$. It is not certain whether this surface low is related to the one shown by Chang and Chen (1995) which appears over the Andaman Sea and the Bay of Bengal, and the southern Indian Ocean. At the same time, a north-south temperature gradient is also established due to the warming over the South China regions and the South China Sea, and the cooling over Australia. These two effects lead to an eastward shift of the $60^{\circ}$ to $80^{\circ} \mathrm{E}$ cross-equatorial flow. Together with the one in $90^{\circ}$ to $110^{\circ} \mathrm{E}$, the low-level crossequatorial flows are enhanced. This results in an increase in low-level convergence in the region of $100^{\circ}$ $120^{\circ} \mathrm{E}, 15^{\circ}-25^{\circ} \mathrm{N}$ which gives rise to the enhanced rising motion which is reflected by the enlargement of the $200-\mathrm{hPa}$ anticyclone on $\operatorname{Day}(0)$. The upperlevel northerlies coming from the eastern part of the enlarged $200-\mathrm{hPa}$ anticyclone then form a prominent return flow with the low-level southerlies which causes a stronger low-level southerly flow and convergence. The cross-equatorial flow also favours the horizontal warm advection to South China from the west. Then a monsoon trough forms along the coast 

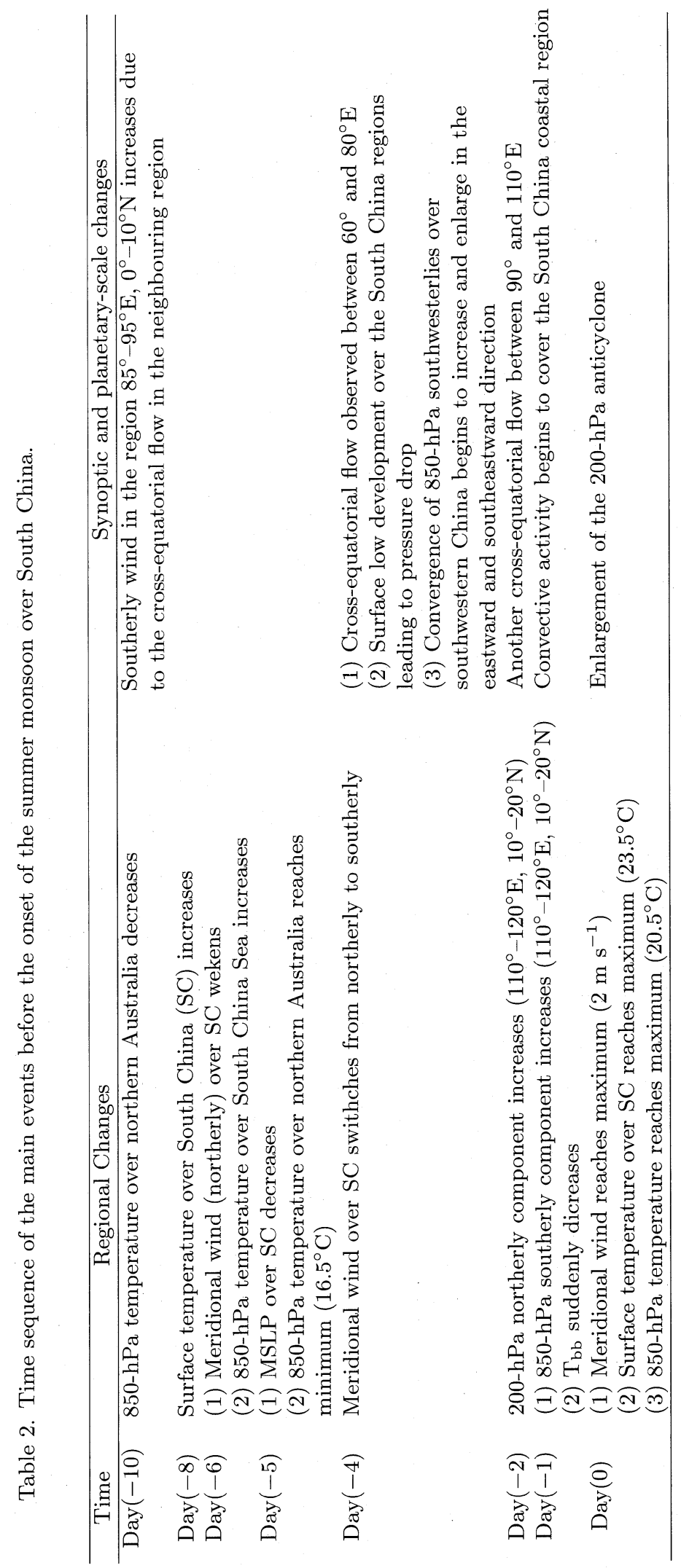


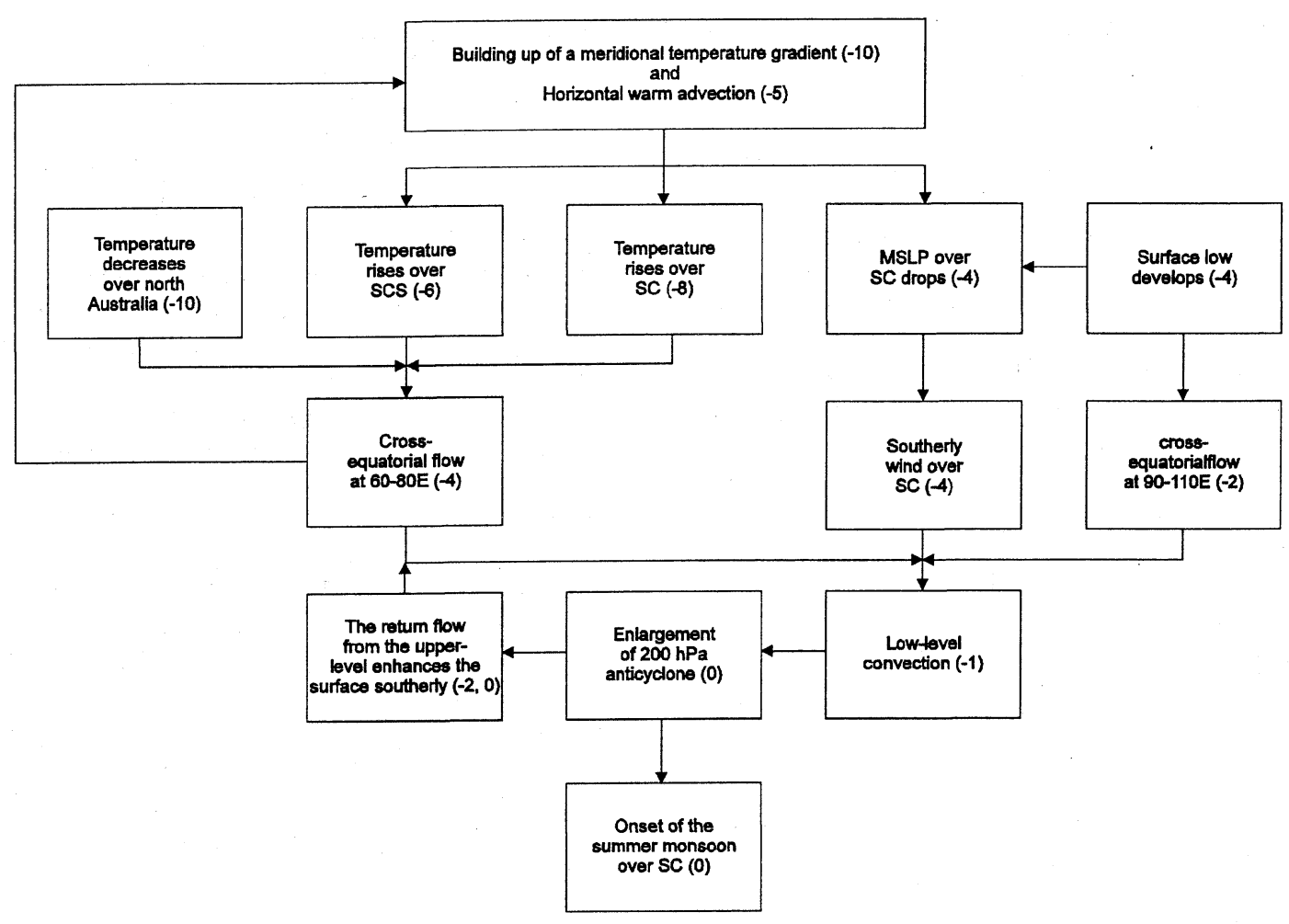

Fig. 12. A flow chart illustrating the sequence of events that lead to the East Asian summer monsoon onset. The numbers in parentheses represent the day relative to onset.

of South China and convective activity increases, as indicated by the $\mathrm{T}_{\mathrm{bb}}$ data, which brings heavy rainfall over the south and southeast China regions. Similar to this trough formation, Chang and Chen (1995) showed that a mid-latitude trough/frontal system appears over the South China Sea during the onset. However, the trough found in this study does not appear to have a high pressure system to its north (see Fig. 5). Therefore, it seems unlikely that it has any frontal characteristics.

\subsection{Future work}

Some primary causes of the onset remain unknown and require further studies. The first one is the cause(s) of the development of surface low pressure system in SC. It is first suspected that the low is generated by lee cyclogenesis. However, the $500-\mathrm{hPa}$ wind flow does not show a propagation of a jet through the $\mathrm{SC}$ regions. It is also possible that the low may be caused by some thermodynamic effects. Further investigation is therefore necessary. The second one is the causes of the temperature rise over the SC and SCS regions. It seems that both diabatic heating and horizontal warm advection can play a role in the heating process. While the former dominates during the earlier phase when convection over the SC region is weak, the latter becomes more important 2 to 4 days before the onset when the cross-equatorial flows begin to develop. Further research will also be needed to clarify the relationship between the monsoon trough found in this study and the mid-latitude trough/frontal system shown by Chang and Chen (1995).

Despite these uncertainties, a general picture of how the onset of the summer monsoon over South China is established. Therefore, the next stage in this research is to study the maintenance and break of the monsoon in order to understand the underlying physical processes governing the monsoon circulation. The methods used will be similar to those used in studying the onset.

\section{Acknowledgments}

The authors would like to thank the Royal Observatory Hong Kong for providing the daily rainfall data, the US NASA Jet Propulsion Laboratory for providing the TOGA CD-ROMs which contain the ECMWF data and the Meteorological Research Institute of Japan for providing the $T_{b b}$ data. Some of the graphics are produced using the Grid Analysis and Display System (GrADS) software provided by the Center for Ocean-Land-Atmosphere Interactions, Department of Meteorology, University of Maryland. Comments from the reviewers and the editor are gratefully acknowledged.

This research is supported by the Research Grants Council of the University Grants Committee of Hong Kong Grant 9040074. 


\section{References}

Chang, C.-P. and G.T.-J. Chen, 1995: Tropical circulations associated with southwest monsoon onset and westerly surges over the South China Sea. Mon. Wea. Rev., 123, 3254-3267.

Chen, G.T.-J., 1994: Large-scale circulations associated with the East Asian summer monsoon and the Meiyu over South China and Taiwan. J. Meteor. Soc. Japan, 72, 959-983.

Chen, L.-X. and W.-L. Li, 1981: The atmospheric heat budget during summer in the Asian monsoon region. Proceedings of the Symposium on the Summer Monsoon in Southeast Asia, August 15-21, 1980, Hongzhou, P.R.C., The People's Press of Yunnan Province, 86-101. (in Chinese).

Chen, T.-C., 1987: 30-50 day oscillation of 200-mb temperature and $850 \mathrm{mb}$ height during the 1979 northern summer. Mon. Wea. Rev., 115, 1589-1605.

Hirasawa, N., K. Kato and T. Takeda, 1995: Abrupt change in the characteriatics of the cloud zone in subtropical East Asia around the middle of May. $J$. Meteor. Soc. Japan, 73, 221-239.

He, H., J.W. McGinnis, Z. Song and M. Yanai, 1987: Onset of the Asian monsoon in 1979 and the effect of the Tibetan Plateau. Mon. Wea. Rev., 115, 19661995

Krishnamurti, T.N. and H.N. Bhalme, 1976: Oscillations of a monsoon system. Part I: Observational aspects. J. Atmos. Sci., 39, 1290-1360.

Lam, S.-H, 1993: Interannual variability and prediction of wet-season and annual rainfall over southern Guangdong. M.Phil Thesis, City Polytechnic of
Hong Kong, 162 pp.

Lau, K.-M. and M.T. Li, 1984: The monsoon of East Asia and its global associations-a survey. Bull. Amer. Meteor. Soc., 65, 114-125.

Matsumoto, J., 1992: The seasonal changes in Asian and Australian monsoon regions. J. Meteor. Soc. Japan, 70, 257-273.

Ninomiya, K. and T. Murakami, 1987: The early summer rainy season (Baiu) over Japan. Monsoon Meteorology, C.P. Chang and T.N. Krishnamurti (Eds.), Oxford Univ. Press, 93-121.

Tanaka, M., 1992: Intraseasonal oscillation and the onset and retreat dates of the summer monsoon over East, Southeast Asia and the western Pacific region using GMS high cloud amount data. J. Meteor. Soc. Japan, 70, 613-629.

Tao, S. and L. Chen, 1987: A review of recent research on the East Asian summer monsoon in China.Monsoon Meteorology, C.P. Chang and T.N. Krishnamurti (Eds.), Oxford Univ. Press, 60-92.

Wang, J.Z. and M.T. Li, 1982: Cross-equatorial flow from Australian monsoon over China. Sci. Atmos. Sinica, 6, 1-10.

Yanai, M., C. Li and Z. Song, 1992: Seasonal heating of the Tibetan Plateau and its effects on the evolution of the Asian summer monsoon. J. Meteor. Soc. Japan, 70, 189-221.

Yang, S., K.M. Lau and M.S. Rao, 1994: Climatology and variability of the Asian summer monsoon in the Goddard Laboratory for Atmospheres CGM. Proceedings of the international conference on monsoon variability and prediction. ICTP, Trieste, Italy, 9-13 May, 815-822. 


\section{香港周辺の華南における夏のモンスーン開始に関する解析的研究}

\section{C.H. So - Johnny C.L. Chan}

(Department of Physics and Material Science, City University of Hong Kong, Hong Kong)

本論文では、香港に扔ける降水量デー夕によって、華南における夏のモンスーン開始期を定義し、その 物理過程を検討した。使用したデータは、1)平均海面気圧、2)地上および高層風、3)地上および $850 \mathrm{hPa}$ の気温、4)黑体温度 (Tbb) の 4 つの気象要素である。1)から 3) はヨーロッパ中期予報センターの格子 点デー夕、4)は静止気象衛星ひまわり 4 号のデータで、対象期間は 1985-90 年である。これらの各気象要 素の日別值を、対象とした 6 年間各年における、夏のモンスーン開始日の前後 10 日間でコンポジットを とって解析した。コンポジット解析の結果、以下のプロセスが明かになった。開始日の 10 日前に、華南 とオーストラリア北部との気温差が、後者の地域での気温の低下によって大きくなる。時間の経過ととも にこの気温差は、華南および南シナ海域での気温上昇により、さらに大きくなる。開始日の 4 日前には、 北緯 18 度・東経 107 度付近のトンキン湾に、地上低気圧ができる。この地上低気圧は、開始期全体を通 じて強まっていく。以上の気温傾度の増大および低気圧の強化にともなって、それまで東経 60-80 度に みられた越赤道気流が東へ移動する。また、東経90-110 度における越赤道気流の別の分枝によって、南 シナ海での下層の南風が強化される。その結果、東経 100-120 度・北緯 15-25 度付近での下層の収束が 増大して、上昇気流が強まる。これは $200 \mathrm{hPa}$ の高気圧が、開始日に拡大することでも確認される。こ の高気圧の東のへリでの北風は赤道に向かう強い反流となる。モンスーントラフは、南シナ海にこうして 形成され、黒体放射温度(Tbb)で示される対流活動が活発になる。これが華南の夏のモンスーン開始である。 